eri käänteissä sulavaa. Mutta olen edelleen fyysisesti hyvin väsynyt.

Entä kuinka kauan täytyy odottaa, että taide ja filosofia ovat jälleen Baseesin kaltaisten konferenssien parrasvaloissa? Tieteidenvälisyys jää monesti historiakonferensseissa ainoastaan kauniiksi sanaksi: yhteiskuntatieteet ja poliittinen historia täyttävät kutsuvierastilan siitäkin huolimatta, että etenkin nykyinen Venäjän historiaa koskeva taiteentutkimus yhdistää sekä yhteiskuntatieteiden että politiikan tutkimuksen menetelmiä. Muun muassa tästä johtuen olin Helsingissä 8. toukokuuta 2019 mukana perustamassa valtakunnallista musiikin ja politiikan tutkimuksen verkostoa.

\section{Elina Viljanen}

\section{Viitteet}

1 Keskustelun voi katsoa internetosoitteessa: https://www.youtube.com/watch?v=ym_jZyHOeDk.

\title{
Kattaus venäläistä nykyelokuvaa: Kino Lokakuu 2019
}

Kino Lokakuu on Suomi-Venäjä-Seuran, Venäjän tiede- ja kulttuurikeskuksen ja elokuvakulttuuriyhdistys Arkadinin perustama venäläistä nykyelokuvaa ja elokuvantekijöitä esittelevä festivaali, joka järjestettiin ensimmäisen kerran vuonna 2006. Helsingin festivaalin jälkeen elokuvia esitetään usein myös muualla Suomessa. Alkuvuosien taiteellinen johtaja Kari Pirhonen muotoili, että tapahtuma "on aina tunnettu synkistä ja lohduttomista elokuvista, elokuvista ilman valoa ja toivoa”. Ehkä näinkin, mutta ohjelmisto on ollut kautta linjan varsin edustava ja teemoiltaan vaihteleva. Tapahtuma pidettiin alun perin nimensä mukaisesti lokakuussa, mutta siirtyi vuonna 2013 helmikuulle. Kahdestoista Kino Lokakuu Tusovka r.y.:n organisoimine lauantai-illan festivaaliklubeineen järjestettiin 12.-17.2.2019 perinteisesti Eerikinkadun Kino Andorrassa ja juhlatila Dubrovnikissa. Avajaispuheenvuoron piti ohjaaja Markku Lehmuskallio, ja avajaiselokuvana nähtiin Vladimir Kottin ohjaama Venäjän syrjäseudulle sijoittuva groteski komedia Thawed Carp (Karp otmorožennyi, "Sulatettu karppi", 2017), jossa entinen opettaja järjestää omia hautajaisiaan.

Tekijävieraat ovat elokuvien ohella Kino Lokakuun keskeistä antia. Vieraiksi on kutsuttu usein nuoria, vielä tuntemattomia tekijöitä, mutta joukossa on ollut sellaisiakin nimiä kuin Aleksei German (1938-2013), Stanislav Govoruhin (1936 -2018), Aleksandr Mindadze (s. 1949) ja Boris Hlebnikov (s. 1972). Tunnettu dokumenttielokuvaaja ja kouluttaja Marina Razbežkina (s. 1948) on vieraillut Kino Lokakuussa useasti. Tämän vuoden vieraisiin lukeutuivat ohjaajat Mihail Segal (s. 1974) ja Denis Šabajev (s. 1980), joita sain tehtäväkseni haastatella heidän elokuviensa esitysten jälkeen.
Mihail Segal on 45-vuotias ohjaaja, kirjailija, käsikirjoittaja, näyttelijä ja säveltäjä. Hän esitteli Kino Lokakuussa uuden elokuvansa Elephants Can Play Football (Slony mogut igrat v futbol, 2018). Se kertoo nelikymppisestä Dmitristä, jolla on hyvä koulutus, hyvä työ ja turvattu elämä. Hän on edelleen nuorekas, mutta hän on myös yksin. Hänen vanhalla opiskelukaverillaan on aikuinen tytär, mutta Dmitrillä ei ole mitään, vain tyhjää. Ensin hänellä ei ole aavistustakaan, miten ryhtyä tyhjyyttä täyttämään, mutta jokin johdattaa hänet tuon opiskelukaverin tyttären seuraan. Elokuvan nimi on siinä kuultava repliikki. Kyse on valtavasta hotellisängystä, jossa Dmitri ei haluaisi nukkua yllätysvieraakseen saapuneen tytön vieressä. Tyttö toteaa, että tilaa kyllä on, siinä norsut mahtuisivat pelaamaan jalkapalloa. Elokuvaa on pidetty Lolita-aiheisena, mutta siitä ei kuitenkaan ole kyse. Mies ei ole kiinnostunut nuorista tytöistä sukupuolisina olentoina. Ja se on jotenkin riipivää, epänormaalia. Miehen asemaan on vaikea asettua, koska hän haluaa sellaista mikä on toisaalta täysin ymmärrettävää, mutta samalla jotenkin väärin tai outoa. Hän haluaa muokata itselleen toisenlaisen elämän: voi jospa hänelläkin olisi oma aikuinen tytär. Jospa voisi hankkia tyttären samalla tavalla kuin uuden vessanpöntön? Mutta ratkaiseeko se mitään?

Mihail Segal valmistui orjolilaisesta yliopistosta vuonna 1994 ja aloitti elokuva-alan opinnot Moskovan elokuvakoulussa (VGIK), mutta jätti koulun kesken tuottaakseen musiikkivideoita tunnetuille venäläisille muusikoille ja yhtyeille, kuten Bi-2, Splean, Kasta ja Mašina vremeni. Kino Lokakuun yleisölle Segalin aikaisemmatkin elokuvat ovat tuttuja. Franz+Polina (2006) kertoo vuoden 1943 Valko-Venäjälle sijoittuvan SS-sotilaan ja paikallisen naisen rakkaustarinan. 
Kertomuksia (Rasskazy, 2012) on puolestaan neljästä episodista koostuva kokonaisuus, joka nojaa kirjalliseen muotoon. Yksi "novelleista" kertoo keski-ikäisestä kustannustoimittajasta ja hänen suloisesta nuoresta rakastajattarestaan, jolle Venäjän ja Neuvostoliiton historia ei merkitse paljoakaan. Hauskasti Segal on ujuttanut tämän pariskunnan käväisemään myös seuraavassa elokuvassaan: Kino pro Aleksejevassa ('Elokuva Aleksejevista", 2014) unohdettu neuvostobardi (Aleksandr Zbrujev) kutsutaan radio-ohjelman vieraaksi ja illan aikana hän saa kadonneen itsekunnioituksensa takaisin. Häkellyttävin jakso on nuoren lauluntekijän (Aleksei Kapitonov) retki Andrei Rubljov -elokuvan (1969) kuvauspaikalle: täysin uskottavan oloinen Andrei Tarkovski (Dmitri Gudotškin) keskustelee näyttelijöidensä kanssa höyryävien teelasien äärellä siitä, mitä on rakkaus, ja päätyy ajatukseen: Rakkaus on sitä, että antaa toiselle ihmiselle sen mitä tämä sillä hetkellä tarvitsee. Elokuvan keskeinen laulu "Dezertir" on ohjaaja Segalin tekemä, ja hän myös esittää sen itse.

Näitä Segalin aikaisempia elokuvia on helppo katsoa, mutta uusi työ on hämmentävä. Mistä tämä Elephants Can Play Football kertoo? Tähän yleisökysymykseen Segal ei vastaa. Hän avaa itseironiseen tyyliinsä taustaansa tavallisten vanhempien lapsena - äiti on opettaja ja isä insinööri - ja toteaa ettei hänellä oikeastaan ole mitään koulutusta siihen mitä hän tekee eli elokuvaan. Mutta yhtä paljon kuin elokuvantekijä, Segal on kirjailija: tekeillä on romaanin käsikirjoitus nähdyn elokuvan aiheista. Kirjallisessa muodossa Segal aikoo kehittää Dmitrin tarinaa edelleen.

Dmitrin henkilö jääkin vielä arvoitukseksi: elokuvassa näytetty ei anna paljoakaan vihjeitä siitä, millainen hän todella on. Tietynlainen töissä - tiukka, asiallinen. Tietynlainen kotona jutellessaan vanhempiensa näyttöruudulla näkyvien torsojen kanssa, tietynlainen pelatessaan kaveriporukan kanssa jalkapalloa, keskittyessään täysin seuraamaan tyttöä lenkkipolulla. Valitessaan kukkia, valitessaan vessanpönttöä... vai onko? Onko hän mitään? Onko hän itse niin tyhjä, että norsut mahtuisivat pelaamaan jalkapalloa? Jostain huokuu samanlaisia tunnelmia kuin itävaltalaisen Michael Haneken elokuvissa - kaikki on periaatteessa hyvin, mutta jokin valtavan ahdistava mörkö vaanii nurkan takana ja saattaa yllättäen sotkea elämän.

Toinenkaan haastattelemani ohjaajavieras ei päästä katsojaa helpolla. Denis Šabajev on syntynyt vuonna 1980 ja opiskellut dokumenttielokuvaa ensin VGIK:issä vuosina 2001-2003 ja Marina Razbežkinan oppilaana vuoteen 2013. Omakohtainen työ Vmeste ('Yhdessä", 2014), viime vuonna Kino Lokakuussa nähty Not $M y$ Job (Tšužaja rabota, "Vierastyö”, 2015) ja uusin elokuva Mira - mies joka halusi rauhaa (Mira, 2018) ovat keränneet palkintoja elokuvafestivaaleilla. Šabajev on muotoillut, että Mira on "rehellinen yritys ymmärtää itäisen Ukrainan tulehtunutta tilannetta". Elokuva sai alkunsa lyhyestä episodista, joka valmistui Lokakuun vallankumousta juhlistaneeseen useamman tekijän elokuvaan 20:17 (2017). Siinä slovakialainen emigrantti Miroslav "Mira” Rogatš esitti itseään, slaavia joka haluaa palauttaa Leninin patsaat takaisin jalustoilleen. Tarina laajeni todellisuutta ja käsikirjoitettua sekoittavaksi elokuvaksi, jossa Mira elää ensin yksitoikkoista elämää itselleen vieraassa Iso-Britanniassa. Hän tutustuu internetissä Donetskin alueella asuvaan naiseen, joka pyytää rahaa. Mira päättää lähteä katsomaan, millaista itäisessä Ukrainassa on. Miran tausta tulee keskusteluissa esiin: hän on entinen sotilas ja istunut vankilatuomion taposta. Miraa ei pelota lähteä sotatoimialueelle. Nainen, joka on pyytänyt rahaa, yrittää vain tulla toimeen. Hän on tutustunut myös muihin miehiin ja pyytänyt rahaa heiltäkin. Mira ei hätkähdä tästäkään. Jotain järjellistä tekemistä täytyy kuitenkin keksiä, ja sellaista löytyy neuvostoaikaisten patsaiden kunnostamisesta.

Mira-elokuvassa nähdään, että ihmiset asuvat ja elävät Donetskissa miten kykenevät. Sota on olosuhde, kukaan ei sitä halua mutta omaa on puolustettava. Rintamalinjojen vastakkaisilla puolilla on ihmisiä, jotka ovat samaa kansaa, puhuvat samaa kieltä ja syövät samaa ruokaa. Slovakialainen emigrantti on kuin kotonaan enemmän kuin missään muualla. Mira ei tarjoa vastauksia, mutta näyttää tilanteen, jossa ei olla oikein missään: jonkin jälkeen ja jotain ennen, välitilassa, kummallisella vyöhykkeellä. Jotenkin Šabajev onnistuu kertomaan siitä, miten kaikesta tuli Neuvostoliiton hajoamisen jälkeen hajanaista, sekavaa ja vaikeaa, eikä kukaan oikein löydä omaa paikkaansa. Kysymykseen olisiko parempi, jos Neuvostoliitto ei olisi hajonnut, Šabajev sanoo ettei sellaista vaihtoehtoa varmaan ole, kyllä hajoaminen oli välttämätöntä. Mutta hän ei pysty puhumaan oman isänsä kanssa Ukrainan tapahtumista, koska heidän käsityksensä ovat aivan vastakkaiset.

Suomi-Venäjä-Seuran kulttuurisihteerin Merja Jokelan kokoamassa monipuolisessa ohjelmistossa oli tänä vuonna jokaiselle jotakin. Dunja Smirnovan elokuvassa Tarina eräästä kohtaamisesta (Istorija odnogo naznatšenijal 
The Tolstoy Defence, 2018) kreivi Leo Tolstoilta pyydetään apua syylliseksi lavastetun sotilaan puolustamisessa. Toiseen maailmansotaan sijoittuvat Puolan kuolemanleiristä kertova humaani Sobibor (2018, ohj. Konstantin Habenski) ja lapsen silmin nähty Anna's War (Voina Anny, 2018, ohj. Aleksei Fedortšenko). Kantemir Balagovin palkittu esikoisohjaus Closeness (Tesnota, "Läheisyys", 2017) on kitkerä kuvaus nuoren naisen ratkaisusta mahdottomassa tilanteessa. Tarjolla oli myös Eduard Novikovin jakuutinkielinen The Lord Eagle (Toyon kyyl, 2018) ja tataarinkielinen Mullah (2018), jonka esityksen jälkeen Jukka Mallinen haastatteli Tatarkinon johtajatarta Miljaguša Aituganova Ljabibovnaa. Festivaalin päätöselokuvana nähtiin palkittu Core of the World (Serdtse mira, 2018). Se kertoo erämaassa asuvasta eläinlääkäristä, joka ymmärtää paremmin eläimiä kuin ihmisiä. Elokuvan käsikirjoittaja ja ohjaaja Natalija Meštšaninova ja hänen näyttelijämiehensä, pääroolin tehnyt
Stepan Devonin tavattiin festivaalin päättäneessä keskustelussa, jossa heitä haastatteli Velipekka Makkonen. Vuoden 2019 uutena kategoriana esitettiin valikoima venäläisiä lyhytelokuvia, valitettavasti myös yksi tekijänsä viimeiseksi työksi jäänyt: Armenian vallankumouksesta kertovan dokumentin Viimeinen päivä (Posledni den, 2018) tehnyt Aleksandr Rastorgujev (19712018) sai surmansa viime vuonna työtehtävissä Keski-Afrikan tasavallassa.

Kino Lokakuu järjestettiin tutuksi tulleessa Andorrassa ja Dubrovnikissa nyt viimeisen kerran: alkukesästä remonttiin menevä Rakennusmestarien talo muutetaan hotelliksi ja historiaan jäävät myös legendaariset baarit Corona ja Kafe Moskova. Epäilemättä korvaava paikka festivaalille löytyy, ja venäläisen elokuvan uudet tuulet pääsevät puhaltamaan meillä myös ensi vuonna.

\section{Mia Öhman}

\section{Konstruktivismia Moskovan kaduilla}

Kiinnostus varhaisen Neuvostoliiton konstruktivistiseen arkkitehtuuriin on viime vuosina lisääntynyt niin Venäjällä kuin ulkomaillakin. Neuvostoliiton 1920-luvun kirjalliset ja kuvataiteelliset kokeilut ovat yleisesti tunnettuja, ja arkkitehtuuristakin tiedetään utopistisimmat ja usein toteuttamatta jääneet kohteet, kuten Kolmannen internationaalin muistomerkki eli niin sanottu Tatlinin torni. Nyt huomiota ovat kuitenkin saaneet myös arkisemmat rakennukset. Tällaisia ovat esimerkiksi Pietarin Traktornaja ulitsan pienkerrostalot, jotka Narvan aukion tuntumassa muodostavat yhtenäisen puutarhakorttelin avarine sisäpihoineen.

Konstruktivistisen rakentamisen keskus oli kuitenkin itseoikeutetusti 1920-luvulla uusi pääkaupunki Moskova, ja sinne ehtikin nousta eniten tyylisuuntaa edustavia rakennuksia. Konstruktivismin tavoitteena oli hyödyntää uusinta rakennustekniikkaa ja -taitoa ihmisten hyvinvoinnin edistämiseksi. Aineellisesti ahtaissa oloissa liike joutui myös turvautumaan luoviin ratkaisuihin. Nykynäkökulmasta oudonkin näköiset talot eivät tavoitelleet taiteellista erikoisuutta sinänsä, vaan toimivat uutta elämää luomaan pyrkineen tyylisuunnan lippulaivoina. Stalinin kaudella 1930-luvulla konstruktivismi koki maineenmenetyksen ja korvautui pompöösillä stalinistisella klassismilla pylväineen kaikkineen. Tyylisuunta ei enää neuvostoaikana koskaan kunnolla elpynyt, ja monet 1920-luvulla rakennetut kohteet ehtivät rapistua tai kadota kokonaan.

Viime vuosina konstruktivistinen arkkitehtuuri on kuitenkin kokenut pienen renessanssin. Alkuperäisiä kohteita pyritään restauroimaan tai ainakin ne halutaan asettaa suojelun alaisiksi, jolloin niiden purkaminen uudisrakentamisen tieltä estettäisiin. Osa suojelutoimista on yksityisten tahojen aikaansaamia, toisissa on mukana myös Venäjän valtio. Muutamat uudet arkkitehtitoimistot ovat jopa ottaneet konstruktivismin yhdeksi suunnannäyttäjäkseen uusien rakennusten suunnittelussa. Moskovalaisen valokuvaaja Natalia Melikovan perustama The Constructivist Project -sivusto (theconstructivistproject.com) tuo esiin Neuvostoliiton konstruktivistisen arkkitehtuurin historiaa ja sen perintöä uudella Venäjällä. Sivusto ylläpitää myös tietokantaa rakennuksista.

Moskovan arkkitehtuurista kiinnostuneille on julkaistu myös kartta Konstruktivistskaja karta Moskvy, jonka avulla löytää viisikymmentä säilynyttä ja tutustumisen arvoista konstruktivismin helmeä. Tässä kuvaesseessä esitellään joitain näistä tunnetuimmista rakennuksista. Valokuvat ovat jutun tekijän maaliskuussa 2019 ottamia.

Teksti ja kuvat: Ville-Juhani Sutinen 